\title{
COMPREHENSION AND ACCEPTABILITY OF A PATIENT INFORMATION LEAFLET (PIL) FOR ANTIRETROVIRAL THERAPY
}

\section{Betty Mwingira}

B Pharm, MSc

Postgraduate pharmacy masters student, Faculty of Pharmacy, Rhodes University

\section{Ros Dowse}

B Pharm, PhD

Associate Professor, Faculty of Pharmacy, Rhodes University

Corresponding author: r.dowse@ru.ac.za

Keywords: "patient information leaflet"; design; readability; acceptability; antiretrovirals

\section{ABSTRACT}

The patient information leaflet (PIL) is recognised as playing a key role in informing patients about their medicines. The objectives of this research were to evaluate the readability and understanding of a PIL for the first-line ARV (antiretroviral) regimen available in the South African public health sector, and investigate its acceptability in the target Xhosa population. The study took place between August 2003 and July 2004. A PIL was designed for the antiretroviral regimen of stavudine, lamivudine and efavirenz, using established usability guidelines. South African legal requirements concerning PILs were incorporated and the PILs were available in both English and isiXhosa. Sixty Xhosa participants between the ages of 18 and 61 years old, with varied levels of education, ranging from no schooling to tertiary level education, were interviewed and demographic data were collected. All participants had stated that they could read. They were asked to read the PIL and a series of questions was asked to assess its comprehension and acceptability. The overall average rate of understanding was $80 \%$. Six of the 20 questions were located and understood by all participants, and only two questions resulted in less than an $85 \%$ correct response. The PIL was rated as difficult to read by only three participants. Physical appearance and quantity of information were highly rated and all participants were enthusiastic about the inclusion of pictograms.

\section{OPSOMMING}

Daar word algemeen aanvaar dat die pasiëntinligtingsblaadjie (PIB) 'n sleutelrol speel in die oordra van inligting ten opsigte van medikasie aan pasiënte. Die doelwitte van hierdie navorsing was om die leesbaarheid en begrip van ' $n$ PIB vir die eerste-linie antiretrovirale (ARV) regimen wat in die Suid-Afrikaanse openbare gesondheidsektor beskikbaar is, te evalueer, en om die aanvaarbaarheid daarvan in 'n teiken-Xhosabevolking te ondersoek. Die studie het tussen Augustus 2003 en Julie 2004 plaasgevind. 'n PIB is vir die antiretrovirale behandelingsregimen van stavudien, lamivudien en efavirens ontwerp deur gebruik te maak van gevestigde gebruiksriglyne. Die Suid-Afrikaanse regsvereistes ten opsigte van PIBs is geïnkorporeer en die PIBs is in beide Engels en isiXhosa beskikbaar gestel. Onderhoude is gevoer met 60 Xhosa deelnemers tussen die ouderdomme van 18 en 61 jaar. Hulle het verskillende opvoedingsvlakke gehad, wat gestrek het van geen skoolopleiding tot tersiêre opleiding, en demografiese data is ingesamel. Al die deelnemers het beweer dat hulle kan lees. Hulle is gevra om die PIB te lees en ' $n$ reeks vrae is gestel om die blaadjie se begrip en aanvaarbaarheid vas te stel. Die algehele gemiddelde mate van begrip was $80 \%$. Ses uit die 20 vrae is deur al die deelnemers korrek uitgewys en verstaan en slegs twee vrae het minder as ' $n$ $85 \%$ korrekte reaksie opgelewer. Slegs drie deelnemers het die PIB as moeilik om te lees, beskou. Beide die fisiese voorkoms asook die hoeveelheid inligting is hoog aangeslaan en alle deelnemers was entoesiasties oor die insluiting van piktogramme. 


\section{INTRODUCTION}

Of the estimated 40 million people infected with HIV worldwide, approximately $70 \%$ live in Sub-Saharan Africa (UNAIDS, 2004). South Africa is the worst affected country with an estimated 5.3 million HIV-infected people and $21.5 \%$ of the population infected (UNAIDS, 2004). AIDS is a chronic condition with no cure. Its management involves combination therapy using a minimum of three antiretroviral (ARV) drugs concurrently, a type of therapy termed highly active antiretroviral therapy (HAART). This is chronic, complex therapy which demands extremely high adherence levels of more than $95 \%$, as poor adherence has been associated with the development of resistance and ultimate therapy failure (Paterson, Swindells, Mohr, Brester, Vergis, Squier, Wagener \& Singh, 2000:27).

Patients initiated on ARV drugs receive an enormous amount of information at a time when they are physically and emotionally challenged, and they are expected to adhere to a complex medication regimen which includes drugs that often result in undesirable side effects. Written patient information materials may be of particular value for these patients when a large volume of information is communicated verbally, as it serves to reinforce the verbal information and act as a permanent source of reference and as an aid to the recall of information.

The 2003 World Health Organization report on adherence to long-term therapies highlights the factors that may result in non-adherence to antiretroviral therapy (ART), as well as some interventions for improving adherence (WHO, 2003:96-101). A major obstacle in achieving adherence to ART is difficulty in understanding instructions due to lack of proper education. A Cochrane review on interventions that have been shown to improve adherence to ART revealed pharmacist-led patient education and counselling to be of value (Haddad, Inch, Glazier, Wilkins, Bayoumi \& Rourke, 2000). Although a well-informed patient is no guarantee for good adherence to therapy, it is important to avoid unintentional non-adherence through a lack of information or because of inadequate understanding of the information.

Patients require access to appropriate information in order to use medicines safely and effectively (Ley, 1990:xi). The major methods of providing such information are verbal, written or multimedia. Relying solely on verbal information has its limitations, as was demonstrated in a study which showed that, on average, patients had forgotten half of what they had heard from the doctor within five minutes of leaving the consultation room (Kitching, 1990:298). A combination of these methods, therefore, has been suggested and been shown to be beneficial (Ley, 1990:175; Raynor, 1998:83).

Patient education using written materials has increased over the years, albeit mainly in the developed world (Buck, 1998:962; Koo, Krass \& Aslani, 2003:259). Of the various forms of written materials, the patient information leaflet (PIL) is the most widely used method for conveying health and medicine information (Kenny, Wilson, Purves, Clark, Newton, Newton \& Moseley, 1998:471). PILs have been shown to be of benefit in improving patient understanding and knowledge of their medicines, enhancing recall of instructions, reducing medication errors as well as patient anxiety about treatment, and bridging the information gap between patients and healthcare providers (Harvey \& Plumridge, 1991:928; Kitching, 1990:300; Raynor, 1998:83-112; Vander Stichele, Van Haecht, Braem \& Bogaert, 1991:1002). Their use is preferred over verbal counselling as they communicate more information than can be achieved by counselling alone, and they have also been shown to increase patient adherence to medicines, thus improving therapy outcomes and patient satisfaction (Harvey et al. 1991:928; Howard, Wildman, Blain, Wills \& Brown, 1999:124-125; Raynor, 1998:83-112; Savas \& Evcik, 2001:101). However, in order to fulfil these functions, the form and quality of the information provided must match the patients' level of education and should take into account culture, beliefs, attitudes and expectations (Dowse \& Ehlers, 2001:87; Doak, Doak \& Root, 1996:41-60; Schaafsma, Raynor \& De Jongvan den Berg, 2003:186)

According to the 2002/3 South African Institute of Race Relations' survey of literacy, the estimated proportion of functionally illiterate people aged 20 and over in 2001 was $28.4 \%$. (South Africa Survey 2002/2003). These estimates are based on the notion that to achieve functional literacy, a minimum of Grade 7 is required (South Africa Survey 2002/2003). This implies that almost a third of the South African population is likely to encounter some difficulty in reading and comprehending written health information. According to research from mainly 
developed countries, one of the most frequently encountered problems with written health information is the use of language at a level higher than the reading skill level of the average patient (Kenny et al. 1998:473; Buck, 1998:964; Baker, 1997:126; Basara \& Jeurgens, 1993:48; Doak et al. 1996:73). This problem is likely to be exacerbated in developing countries where low literacy is more prevalent.

In South Africa, the provision of PILs with all medicines was mandated by Regulation 10 of the Medicines and Related Substances Control Act, Act 101, as amended, from May 2003 (Government Notice, Department of Health, 2003). This regulation requires the pharmaceutical industry to develop and distribute PILs with all their manufactured medicines. The ARV drugs have supposedly received high priority in this initiative (Medicines Control Council, 2004). However, there is little evidence that public sector hospitals have received PILs, designed according to local legal requirements, from the pharmaceutical industry. Feedback on this issue obtained via telephonic communication with a number of public sector hospitals revealed that many are using PILs developed in-house.

As ART includes a minimum of three different drugs, this would normally entail providing a different PIL for each of the three ARV drugs. However, this volume of information would severely challenge the reading skills of the average patient in this country. It was essential, therefore, to attempt to address this problem by developing more appropriate written medicine information for HIV/AIDS patients on ART.

\section{RESEARCH OBJECTIVES}

The objectives of this research were to evaluate the readability and understanding of a PIL for the first-line ARV regimen available in the South African public health sector, and to investigate its acceptability in the target Xhosa population.

\section{METHODS}

\section{Study site and study population}

The study was conducted between August 2003 and July 2004 in Grahamstown, a small town in the largely rural Eastern Cape, a province which is underdeveloped and economically poor with an extremely high unemployment rate. Twenty percent of the province's population aged 21 or more years have had no schooling, with only $5 \%$ holding a tertiary education (Statistics South Africa, 2001). The majority of the local black population belongs to the Xhosa ethnic group. Participants in the study were randomly drawn from this group and were recruited from a community centre and surrounding areas. Approval for the study was obtained from the Rhodes University Ethical Standards Committee.

\section{Research materials}

The ARV regimen chosen was the alternate first-line regimen (Regimen $1 b$ ) contained in the Operational Plan for Comprehensive HIV and AIDS Care, Management and Treatment for South Africa released by the South African National Department of Health in November 2003 (South African Government Information, 2003). Information on the ARV drugs in this regimen, which consisted of Stavudine, Lamivudine and Efavirenz, was collected and consolidated. All the local legal requirements stated in Regulation 10 were included (Government Notice, Department of Health, 2003). This regulation states: "Each package of a medicine shall have a PIL that must contain the following information (as described) with regard to the medicine in at least English and one other official language."

The PIL was designed using usability guidelines for consumer medicines information (Sless \& Wiseman, 1997) as well as other various validated guidelines on patient information design (Raynor, 1992:181; Koo et al. 2003:261; Doak et al. 1996:73-89). Special attention was paid to ensuring the inclusion of simple words and short sentences to suit the widely varying reading skills of the target population. Seven pharmaceutical pictograms from a number of sources (USP DI 2000:1618-1626; Dowse \& Ehlers, 2001:94-95) were modified, tested and incorporated into the text. A twopage A4 size PIL was developed and modified using feedback from four focus groups each consisting of five members of the target population. These participants were excluded from the final study. The PIL was subjected to Fry's readability test (Doak et al. 1996:44) which allows a quick estimation of readability levels, and was found to be suitable for Grade 7 learners. 
The first version of the PIL was piloted using 20 Xhosa participants. Results from this study were used to refine the questionnaire. No major modifications were necessary, but certain questions were simplified to render them easier to translate. The pilot study also informed minor modifications to the PIL, both in PIL content and layout. The final version of the PIL was then translated into isiXhosa using a multistage approach of translation by a professional translator, professional proofreading and back translation. This final version was evaluated in 60 Xhosa participants who had a choice of reading either the English or isiXhosa versions of the PIL (Figure 1 on pages $60 \& 61$ ). The sample size of 60 participants was determined using the Z-test for proportions power calculation. With a significance level of $5 \%$ and power $=0.85$, the calculated sample size was 42.7. The sample size of 60 resulted in the power of the test to be 0.87 .

\section{Interview process and data collection}

A questionnaire was developed for data collection. Two people were involved in the data collection; the researcher, and the interpreter who had received specialised training and who had participated in a number of our previous research projects. Interviews were conducted during the day in either a room in the community centre or in the participants' homes. Potential participants were approached in the community centre by the interpreter who introduced himself and the researcher, explained the purpose of the project and asked if they would like to participate in the project. People in the community centre assisted in the recruitment of participants from the surrounding suburban area.

A standard approach was used for all the interviews in which potential participants were asked if they could read, as this was an inclusion criterion. It was emphasised to the participants that this study was to evaluate the quality of the information materials and was not a test of their reading skills.

Selected demographic data were collected (gender, race, age, home language, educational level). Participants were then handed the PIL and were asked to read through it at their leisure. The time taken to read the PIL was discreetly recorded using a stopwatch. The testing process used is based on that pioneered by the Communication Research Institute of Australia
(Dickinson, Raynor \& Duman, 2001:147; Sless \& Wiseman, 1997), whereby participants were asked a series of 20 questions. Each question had two parts; firstly, participants were required to locate the information pertaining to the question in the PIL, and secondly, they were asked to explain that information in their own words so as to evaluate comprehension. Understanding of the information was calculated according to the number of answers correctly located and explained. Acceptability of the PIL was then investigated by asking a number of set questions as well as encouraging open-ended feedback from all participants. At the conclusion of the interview, participants were thanked and were given a small honorarium of R20 in acknowledgement of their time and contribution to the study. When agreeing to participate in the study, participants from the focus groups, pilot study and main study were not aware that they would be given an honorarium.

\section{Data analysis}

Feedback from the focus groups was recorded on paper and this information provided the basis for the initial development and modification phases. An understanding score for the PIL was calculated based on the number of questions answered correctly. Understandability was assessed using the European Commission (EC) guideline (Dickinson et al. 2001:148) which sets a target that at least $80 \%$ of the participants correctly answer each question, in that they should both locate the appropriate information and be able to explain it in their own words.

\section{Validity and reliability of data}

Reliability, which refers to the extent to which procedures, measures and data are reproducible and internally consistent (Smith, 2005:60) was ensured in this study in a number of ways: only one researcher was used for data collection, an experienced interpreter was specially trained for these interviews, and the interview process was standardised with close adherence to the interview schedule by the researcher progressing through the questionnaire systematically.

Validity refers to the extent to which the measures provide a true measure of what they are designed to measure (Smith, 2005:60). The importance of external va- 
lidity, or generalisability, was ensured in the sampling strategies and recruitment procedures described previously in the Methods section. Internal validity of the research instrument was considered in the construction of individual questions and the conducting of the pilot study which allowed identification of problems arising from question structure and interpretation.

\section{RESULTS}

\section{Demographic characteristics}

The demographic characteristics of the 60 participants are presented in Table 1. There was an even distribution of males to females and the majority $(80 \%)$ of the participants were aged between 21 and 40 years. More than half were unemployed. Of the 11 participants with less than five years of schooling, five were considered to be poor readers. On observing these participants while they read the PIL, it was evident that all but one of the five failed to use the headings in the PIL to navigate their way through the PIL and they struggled with locating the information. Fifty-two participants (86.7\%) were categorised as good readers as they encountered no problems in navigating through the PIL, using the headings appropriately in order to locate the information.

Table 1: Demographic characteristics $(n=60)$

\section{Understanding of the PIL}

The average time taken to read the PIL was nine minutes, with only three participants reading it in under five minutes and the majority (68\%) taking between five and 10 minutes. Generally, most of the information in the PIL was well located and understood (Table 2). The average overall rate of understanding was $80 \%$. Six of the 20 answers to questions were located and understood by all participants. The target set by the EC guideline that at least $80 \%$ of participants should answer each question correctly was achieved for 18 of the 20 questions.

Question 3 was the most challenging question, with only $40 \%$ of the participants able to comprehend the possibility of developing resistance if the medicines were not taken as instructed. Given the seriousness of this possible outcome of poor adherence, the PIL requires modification to make this information more conspicuous and understandable. The other question that failed to meet the EC target dealt with allergies and taking ARV drugs (Question 12). As with Question 3, this is a twopart complex question, firstly requiring the participant to identify with a condition, for example, having an allergy, and then requiring an understanding of the consequences of not obeying an instruction. In both

\begin{tabular}{|c|c|}
\hline Demographic Characteristic & Participants n(\%) \\
\hline \multicolumn{2}{|l|}{ Gender } \\
\hline Male & $30(50.0)$ \\
\hline Female & $30(50.0)$ \\
\hline \multicolumn{2}{|l|}{ Age (yr) } \\
\hline$<21$ & $3(5.0)$ \\
\hline $21-40$ & $48(80.0)$ \\
\hline $41-65$ & $9(15.0)$ \\
\hline \multicolumn{2}{|l|}{ Number of years in school } \\
\hline $0-5$ & $11(18.3)$ \\
\hline $6-11$ & 20 (33.3) \\
\hline$>11$ & $29(48.3)$ \\
\hline \multicolumn{2}{|l|}{ Employment } \\
\hline Yes & $18(30.0)$ \\
\hline No & $42(70.0)$ \\
\hline
\end{tabular}


Table 2: Number (\%) of participants correctly locating and understanding information in the PIL ( $n=60)$

\begin{tabular}{|c|c|c|}
\hline Questions & & $\begin{array}{l}\text { Participants } \\
\text { n (\%) }\end{array}$ \\
\hline $\begin{array}{l}\text { 1. Using the leaflet, can you tell me the name of these medicines } \\
\text { and describe them? }\end{array}$ & Located & $60(100.0)$ \\
\hline 2. Can one still spread HIV/AIDS while taking these medicines? & $\begin{array}{l}\text { Located } \\
\text { Understood }\end{array}$ & $\begin{array}{l}59(98.3) \\
52(86.7)\end{array}$ \\
\hline $\begin{array}{l}\text { 3. If you do not take your medicines as instructed, what may } \\
\text { happen? }\end{array}$ & $\begin{array}{l}\text { Located } \\
\text { Understood }\end{array}$ & $\begin{array}{l}59(98.3) \\
24(40.0)^{1}\end{array}$ \\
\hline $\begin{array}{l}\text { 4. According to the leaflet, how many times a day must you take } \\
\text { Stavudine (d4T) capsules }\end{array}$ & $\begin{array}{l}\text { Located } \\
\text { Understood }\end{array}$ & $\begin{array}{l}60(100.0) \\
60(100.0)\end{array}$ \\
\hline $\begin{array}{l}\text { 5. Looking at the leaflet, does it tell you what to do if you miss a } \\
\text { dose of your medicines? }\end{array}$ & $\begin{array}{l}\text { Located } \\
\text { Understood }\end{array}$ & $\begin{array}{l}58(96.7) \\
58(96.7)\end{array}$ \\
\hline $\begin{array}{l}\text { 6. Like any other medicines, these medicines have both good and } \\
\text { bad effects. Does the leaflet tell you what the bad effects are and } \\
\text { what you should do if you experience any of them? }\end{array}$ & $\begin{array}{l}\text { Located } \\
\text { Understood }\end{array}$ & $\begin{array}{l}60(100.0) \\
60(100.0)\end{array}$ \\
\hline 7. What do these medicines do to the viral load? & $\begin{array}{l}\text { Located } \\
\text { Understood }\end{array}$ & $\begin{array}{l}58(96.7) \\
55(91.7)\end{array}$ \\
\hline $\begin{array}{l}\text { 8. What does the leaflet tell you to do if you take too much of these } \\
\text { medicines by mistake? }\end{array}$ & $\begin{array}{l}\text { Located } \\
\text { Understood }\end{array}$ & $\begin{array}{l}56(93.3) \\
56(93.3)\end{array}$ \\
\hline 9. Do these medicines cure HIV/AIDS? & $\begin{array}{l}\text { Located } \\
\text { Understood }\end{array}$ & $\begin{array}{l}60(100.0) \\
59(98.3)\end{array}$ \\
\hline $\begin{array}{l}\text { 10. According to the leaflet, if you are taking any other medicines, } \\
\text { what should you do before taking these medicines? }\end{array}$ & $\begin{array}{l}\text { Located } \\
\text { Understood }\end{array}$ & $\begin{array}{l}59(98.3) \\
59(98.3)\end{array}$ \\
\hline 11. How long do you have to take these medicines for? & $\begin{array}{l}\text { Located } \\
\text { Understood }\end{array}$ & $\begin{array}{l}59(98.3) \\
59(98.3)\end{array}$ \\
\hline $\begin{array}{l}\text { 12. According to the leaflet, if you have any allergies, what should } \\
\text { you do before taking these medicines? }\end{array}$ & $\begin{array}{l}\text { Located } \\
\text { Understood }\end{array}$ & $\begin{array}{l}59(98.3) \\
38(68.3)^{1}\end{array}$ \\
\hline $\begin{array}{l}\text { 13. Does the leaflet tell you how many of Efavirenz (EFV) capsules } \\
\text { you should take each time? }\end{array}$ & $\begin{array}{l}\text { Located } \\
\text { Understood }\end{array}$ & $\begin{array}{l}60(100.0) \\
59(98.3)\end{array}$ \\
\hline $\begin{array}{l}\text { 14. Suppose you have been feeling better for the past month; Can } \\
\text { you stop taking your medicines? }\end{array}$ & $\begin{array}{l}\text { Located } \\
\text { Understood }\end{array}$ & $\begin{array}{l}58(96.7) \\
59(98.3)\end{array}$ \\
\hline 15. What should you do with left over medicines? & $\begin{array}{l}\text { Located } \\
\text { Understood }\end{array}$ & $\begin{array}{l}58(96.7) \\
59(98.3)\end{array}$ \\
\hline $\begin{array}{l}\text { 16. Some medicines can be taken with alcohol. Can you take } \\
\text { alcohol while taking these medicines? }\end{array}$ & $\begin{array}{l}\text { Located } \\
\text { Understood }\end{array}$ & $\begin{array}{l}60(100.0) \\
60(100.0)\end{array}$ \\
\hline 17. Does the leaflet tell you how to store these medicines? & $\begin{array}{l}\text { Located } \\
\text { Understood }\end{array}$ & $\begin{array}{l}60(100.0) \\
60(100.0)\end{array}$ \\
\hline $\begin{array}{l}\text { 18. Is there any advice in this leaflet about sharing your medicines } \\
\text { with someone else who has HIV/AIDS? }\end{array}$ & $\begin{array}{l}\text { Located } \\
\text { Understood }\end{array}$ & $\begin{array}{l}59(98.3) \\
59(98.3)\end{array}$ \\
\hline
\end{tabular}

${ }^{1}$ Questions that failed to reach the EC target of $80 \%$ 
cases, location of the information was excellent, but participants were unable to understand and use the located information to inform their own medicine-related behaviour.

Many of the participants admitted to not understanding certain words. The terms 'viral load', 'CD4 count' and 'antiretroviral therapy' were poorly understood by $80 \%$ of the participants, 'resistance' by $12 \%$, 'pharmacist' by $10 \%$ and 'capsules' by $5 \%$.

All except one of the instructions that were illustrated by pictograms scored $100 \%$, a finding which supports research by Mansoor and Dowse (2003:1006) who also showed a positive influence of pictograms on the understanding of textual information in a similar population.

\section{Acceptability of the PIL}

Interestingly, of the 60 participants, $30 \%$ chose to read the English version of the PIL, even though they were literate in isiXhosa. Some stated that they were more comfortable reading English as they routinely used it in their studies and at work. They considered the English words to be easier to understand and simpler than the isiXhosa translations.

Table 3 illustrates that the physical appearance of the PIL appealed to the majority of the participants. Only three of the 60 participants found it "difficult" to read, with a third finding it "easy" to read. The general consensus was that the font size was sufficiently large, the length of the sentences was reasonable and there was adequate space between the lines of text.

A majority of the participants (88.3\%) thought the information in the PIL was sufficient to guide them in using these medicines appropriately. Significantly, all 60 participants liked having pictures in the PIL and were of the opinion that the pictures would contribute to understanding and recalling the information. The level of difficulty of the words used appeared to be appropriate as only one participant stated that he was unable to understand many of the words. The majority understood most of the words, with only a few words presenting problems. Participants were appreciative of being able to choose the language of the PIL. Forty-four of the 60 (73.3\%) stated that they would prefer to receive PILs in their home language of isiXhosa.

\section{DISCUSSION}

Inadequate patient education and information have been identified as factors contributing to poor adherence with ART. This study attempted to address this by developing a user-friendly, comprehensive, readable PIL for the first-line ARV regimen used in South Africa. The information for the three individual ARV drugs constituting this regimen was integrated into a single PIL that was designed according to established good design principles, taking into account both content and format of the information, as well as consumer evaluation of the material. The success of this approach in developing written medicines information is evident from the high levels of understanding of the PIL found in this study.

Most research on written medicine information originates from developed countries, with a limited number of studies having investigated the design, value or use of PILs in developing countries (Mansoor \& Dowse, 2003:1003; Van Schoor, 1993; Van Zoest, 1999). The study setting for the research is of great significance when referring to research outcomes for guidance in developing written medicines information, as the characteristics of the target patient populations are likely to be very different. It is known that patient education materials which have been designed and evaluated taking into account reading levels, culture and beliefs of the target population are better understood and accepted (Buck, 1998:964; Doak et al. 1996:41-60; Mansoor \& Dowse, 2003:1003). In this study, the PIL was designed in close collaboration with focus groups consisting of members from the target population and was subsequently evaluated in this population, which undoubtedly played a crucial role in contributing to its success.

Research has demonstrated the benefits of incorporating pharmaceutical pictograms into written medicines information (Dowse \& Ehlers 2005:68; Mansoor \& Dowse, 2003:1003; Sojourner \& Wogalter, 1998:103). A study conducted in a low-literate South African population conclusively showed that medicines information incorporating pictograms was significantly better comprehended than documents containing text only, and it was the preferred format (Mansoor \& Dowse, 2003:1006). Results from this study support these find- 
Table 3: Participant acceptability of the PIL $(n=60)$

\begin{tabular}{|c|c|c|}
\hline Questions & Response & $\begin{array}{l}\text { Participants } \\
\text { n (\%) }\end{array}$ \\
\hline \multicolumn{3}{|l|}{ Readability } \\
\hline How easy was it to read this leaflet? & $\begin{array}{l}\text { Easy } \\
\text { Average } \\
\text { Difficult }\end{array}$ & $\begin{array}{l}20(33.3) \\
37(61.7) \\
3(5.0)\end{array}$ \\
\hline Is the writing large enough? & $\begin{array}{l}\text { Yes } \\
\text { No }\end{array}$ & $\begin{array}{l}60(100.0) \\
0(0.0)\end{array}$ \\
\hline What do you think of the length of the sentences? & $\begin{array}{l}\text { Too long } \\
\text { Right } \\
\text { Too short }\end{array}$ & $\begin{array}{l}2(3.3) \\
57(95.0) \\
1(1.7)\end{array}$ \\
\hline Is there enough space between the lines? & $\begin{array}{l}\text { Too wide } \\
\text { Right size } \\
\text { Too small }\end{array}$ & $\begin{array}{c}1(1.7) \\
58(96.7) \\
1(1.7)\end{array}$ \\
\hline \multicolumn{3}{|l|}{ Amount of information } \\
\hline $\begin{array}{l}\text { If you had just started taking these medicines and this was } \\
\text { all the information you were given about them, do you think } \\
\text { it is enough? }\end{array}$ & $\begin{array}{l}\text { Yes } \\
\text { No }\end{array}$ & $\begin{array}{l}53(88.3) \\
7(11.7)\end{array}$ \\
\hline \multicolumn{3}{|l|}{ Pictograms } \\
\hline Do you like having pictures in the leaflet? & $\begin{array}{l}\text { Yes } \\
\text { No }\end{array}$ & $\begin{array}{l}60(100.0) \\
0(0.0)\end{array}$ \\
\hline $\begin{array}{l}\text { Do you think the pictures will help you understand and } \\
\text { recall the information better? }\end{array}$ & $\begin{array}{l}\text { Yes } \\
\text { No }\end{array}$ & $\begin{array}{l}60(100.0) \\
0(0.0)\end{array}$ \\
\hline \multicolumn{3}{|l|}{ Words in the text } \\
\hline $\begin{array}{l}\text { Are there any words in the text that you did not } \\
\text { understand? }\end{array}$ & $\begin{array}{l}\text { No } \\
\text { Yes, a few } \\
\text { Yes, many }\end{array}$ & $\begin{array}{l}5(8.3) \\
54(90.0) \\
1(1.7)\end{array}$ \\
\hline \multicolumn{3}{|l|}{ PIL language preference } \\
\hline In what language would you prefer to read the leaflet? & $\begin{array}{l}\text { English } \\
\text { isiXhosa }\end{array}$ & $\begin{array}{l}16(26.7) \\
44(73.3)\end{array}$ \\
\hline
\end{tabular}

ings as the presence of pictograms elicited positive comments from all participants, with the illustrated instructions being excellently comprehended.

For medicines information to stimulate interest, it should be user-friendly, attractive, easily readable and accessible. Consumer testing, in which consumer preferences are evaluated via open-ended questions, is the best way to assess this and forms an important part of the design process of PILs (Dickinson et al. 2001:156).
This study employed a combination of open- and closeended questions to ascertain participant opinion and preference, and this process provided us with invaluable input for modifying the document and optimising its physical appearance, user-friendliness and readability.

In general, people prefer and have a better understanding of easy-to-read materials, irrespective of their educational level (National Work Group on Literacy and 
Health, 1998:171). Medicines information intended for patients, therefore, should be written in the simplest form possible for optimal acceptance and understanding, particularly if the target population contains a significant proportion of patients with limited reading skills (Ley, Jain \& Skilbeck, 1976:600; Savas \& Evcik, 2001:101-102). A common problem encountered in written health information is the use of language at a level higher than the reading skill of the average patient (Buck, 1998:964; Doak et al. 1996:73). In the design phase of this study, particular attention was paid to both the amount of information included and the difficulty of the words used. Wherever possible, linguistically transparent words and commonly used phrases that were familiar to the target population were incorporated. Most of the medical terminology associated with HIV/AIDS is fairly new. Although the terms 'viral load', 'CD4 count', 'antiretroviral therapy' and 'resistance' were poorly understood, there are no substitutes. Explanations describing these words in lay terms were included so as to aid their comprehension. These problem words may have contributed to a lack of continuity in reading the PIL and a subsequent lack of understanding of the entire meaning of some of the sentences. However, it should be borne in mind that the participants were apparently healthy volunteers who were not taking ARV drugs. Any HIV-positive patient would, through counselling, undoubtedly become familiar with these HIV/ AIDS-related terms.

The distribution of PILs in the home language of patients has been shown to be superior in aiding their utility and acceptance (Schaafsma et al. 2003:188). In this study, the general consensus was that PILs should be available in the patients' language of choice, sending a clear message that such materials must be made available in a variety of languages to satisfy the diverse South African population.

Current South African legislation stipulates the information that is to be included in PILs, but makes no mention of their format, design or evaluation (Government Notice, Department of Health, 2003). The required inclusion of a product description section elicited a general consensus of being too technical and of little value to the patient in contributing to safe and effective medicine taking. In fact it was considered to be a detracting factor in that it adversely increased the overall length of the PIL. Results such as these should be taken into account by regulatory bodies when deciding on essential drug-related information meant specifically for patients, many of whom, in this country, may have limited reading skills. Despite major attempts to simplify the PIL used in this study, we were constrained by local legal requirements, resulting in a written document that was found to have a readability level of Grade 7 which exceeds that of $20 \%$ of the target population.

In May 2004, the South African Medicines Control Council published the first version of a document entitled "Guideline on the Requirements for Patient Information Leaflets" (Medicines Control Council, 2004). This document provides guidance to applicants on the content, format and readability of PILs intended for the South African market, and aims to ensure that the PIL is written in clear and understandable terms for the patient and is clearly legible. However, there is no requirement for evaluation of the final product prior to distribution and it is uncertain whether PILs developed using these guidelines will appropriately cater for the enormous diversity of the South African population.

\section{LIMITATIONS OF THE STUDY}

This PIL was tested only in the Xhosa ethnic group and extrapolation of results to other language groups in South Africa must be done with caution. Testing of translated materials in other language groups will be necessary prior to use. The use of interpreters introduces an additional variable. To ensure quality and consistency in the communication between interpreter and participant, the interpreter was appropriately trained prior to the interviews. It was emphasised that a standard approach should be used in all the interviews in order to ensure consistency and validity of the results. Participants interviewed were not patients actually taking the drugs and therefore had no personal vested interest in making a real effort to understand the information. This may have contributed to bias in the results. Further research should include testing the PIL in HIV/ AIDS patients on ART.

\section{CONCLUSIONS}

There is a paucity of comprehensive yet simple, readable and user-friendly medicine information designed specifically for the local market that takes into account 
the widely varying reading skills and cultures of the South African population. An urgent need exists for properly designed medicines information that will cater for the diverse South African population. The PIL designed and tested in this study proved to be well understood and accepted by participants from the target population, representatives of whom were included in the design phase. We recommend careful design and evaluation of all PILs prior to their distribution and use in patients.

\section{ACKNOWLEDGEMENTS}

The authors would like to thank professor Sarah Radloff for her help with the statistics, Rhodes University and Wyeth South Africa for financial support, and the interpreter and participants who contributed to this project.

\section{REFERENCES}

BAKER, SJ 1997: Who can read consumer product information? Australian Journal of Hospital Pharmacy, 27(2):126-131.

BASARA, LR \& JEURGENS, JP 1994: Patient package insert readability and design. American Pharmacy, NS34(8):48-53.

BUCK, ML 1998: Providing patients with written medication information. Annals of Pharmacotherapy, 32(9):962-969. GOVERNMENT NOTICE, DEPARTMENT OF HEALTH, 2003: General regulations made in terms of the Medicines and Related Substances Act, 1965 (Act No. 101 of 1965), as amended.

DICKINSON, D; RAYNOR, DK \& DUMAN, M 2001: Patient education leaflets for medicines: Using consumer testing to determine the most effective design. Patient Education and Counseling, 43(2):147-159.

DOAK, CC; DOAK, LG \& ROOT, JH 1996: Teaching patients with low literacy skills; 2nd edition. Philadelphia: JB Lippincott.

DOWSE, R \& EHLERS, MS 2001: The evaluation of pharmaceutical pictograms in a low-literate South African population. Patient Education and Counseling, 45(2):87-99.

DOWSE, R \& EHLERS, MS 2005: Medicine labels incorporating pictograms: Do they influence understanding and adherence? Patient Education and Counseling, 58(1):63-70.

HADDAD, M; INCH, C; GLAZIER, RH; WILKINS, AL; BAYOUMI, A \& ROURKE, S 2000: Patient support and education for promoting adherence to highly active antiretroviral therapy for HIV/AIDS (Cochrane Review) Issue 3, The Cochrane Library, Oxford: Update Software, 2000. Abstract [Online]. Available: http:// www.cochrane.org/reviews/en/ab001442.html [Accessed: 12 August 2003].
HARVEY, JL \& PLUMRIDGE, RJ 1991: Comparative attitudes to verbal and written medication information among hospital outpatients. Annals of Pharmacotherapy, 25(9):925-928.

HOWARD, J; WILDMAN, K; BLAIN, J; WILLS, S \& BROWN, D 1999: The importance of drug information from a patient perspective. Journal of Social and Administrative Pharmacy, 16(3/4):115126.

KENNY, T; WILSON, RG; PURVES, IN; CLARK, J; NEWTON, LD; NEWTON, DP \& MOSELEY, DV 1998: A PIL for every ill? Patient information leaflets (PILs): A review of past, present and future use. Family Practice, 15(5):471-479.

KITCHING, JB 1990: Patient information leaflets - the state of the art. Journal of the Royal Society of Medicine, 83(5):298-300. KOO, MM; KRASS, I \& ASLANI, P 2003: Factors influencing consumer use of written drug information. Annals of Pharmacotherapy, 37(2):259-267.

LEY, P; JAIN, VK \& SKILBECK, CE 1976: A method for decreasing patients' medication errors. Psychological Medicine, 6(4):599601.

LEY, P 1990: Communicating with patients. New York: CroomHelm.

MANSOOR, L \& DOWSE, R 2003: Effect of pictograms on readability of patient information materials. Annals of Pharmacotherapy, 37(7/8):1003-1009.

MEDICINES CONTROL COUNCIL, 2004: Guidelines on the requirements for patient information leaflets. Document 2.14MAY04V2:May 2004. [Online]. Available: http:// www.mccza.com/showdocument.asp?Cat=17\&Desc=Guidelines \%20-\%20Human\%20Medicines [Accessed: 8 November 2005]. NATIONAL WORK GROUP ON LITERACY AND HEALTH 1998: Communicating with patients who have limited literacy skills. Journal of Family Practice, 46(2):168-176.

PATERSON, DL; SWINDELLS, S; MOHR, J; BRESTER, M; VERGIS, EN; SQUIER, C; WAGENER, MM \& SINGH, N 2000: Adherence to protease inhibitor therapy and outcomes in patients with HIV infection. Annals of Internal Medicine, 133(1):21-30.

RAYNOR, DK 1992: Writing patient information - A pharmacist's guide. Pharmaceutical Journal, 249(6699):180-182.

RAYNOR, DK 1998: The influence of written information on patient knowledge and adherence to treatment. (In: Myers LB \& Midence K eds. 1998: Adherence to treatment in medical conditions. Amsterdam: OPA/Harwood Academic Publishers, pp 83112.)

SAVAS, S \& EVCIK, D 2001: Do undereducated patients read and understand written education materials? Scandinavian Journal of Rheumatology, 30(2):99-102.

SCHAAFSMA, ES; RAYNOR, DK \& DE JONG-VAN DEN BERG, LTW 2003: Accessing medication information by ethnic minorities: barriers and possible solution. Pharmacy World and Science, 
25(5):185-190.

SLESS, D \& WISEMAN, R 1997: Writing about medicines for people: Usability guidelines for consumer medicines information; 2nd edition. Canberra: Australian Government Publishing Service.

SMITH, F 2005: Conducting your pharmacy practice research project. London: Pharmaceutical Press.

SOJOURNER, RJ \& WOGALTER, MS 1998: The influence of pictorials on the comprehension and recall of pharmaceutical safety and warning information. International Journal of Cognitive Ergonomics, 2(1-2):93-106.

SOUTH AFRICA SURVEY 2002/2003: South African Institute of Race Relations: Johannesburg.

SOUTHAFRICAN GOVERNMENT INFORMATION 2003: Operational Plan for Comprehensive HIV and AIDS Care, Management and Treatment for SA [Online]. Available: http://www.info.gov.za/issues/hiv/careplan.htm [Accessed: 23 October 2003].

STATISTICS SOUTH AFRICA CENSUS 2001: Census in Brief [Online]. Available: http://www.statssa.gov.za/census01/html/ CInBrief/CIB2001.pdf [Accessed: 18 September 2004]. UNAIDS 2004: UNAIDS 2004 Report on the global AIDS epidemic [Online]. Available: http://www.unaids.org/bangkok2004/ report.html [Accessed: 20 July 2004].

USP DI Vol. II 2000: Advice for the patient. Drug information in lay language; 20 th edition. 2000: Englewood: Micromedex, Inc.

VANDER STICHELE, RH; VAN HAECHT CH; BRAEM, MD \& BOGAERT MG 1991: Attitude of the public toward technical package inserts for medication information in Belgium. Drug Intelligence and Clinical Pharmacy, 25(9):1002-1006.

VAN SCHOOR, JD 1993: The value of patient information leaflets. Potchefstroom: Potchefstroom University for Christian Higher Education (Unpublished MSc Thesis).

VAN ZOEST, F 1999: Patient package inserts in developing countries: A way to improve appropriate drug use? Netherlands: Netherlands School of Public Health (Unpublished MPh Thesis).

WORLD HEALTH ORGANIZATION 2003: Adherence to long-term therapies: Evidence for action. [Online]. Available: http:// www.who.int/chronic_conditions/adherencereport/en/ [Accessed: 10 August 2004]. 